\title{
Erythrocyte Mean Corpuscular Volume
}

National Cancer Institute

\section{Source}

National Cancer Institute. Erythrocyte Mean Corpuscular Volume. NCI Thesaurus. Code C64799.

The mean cell volume is the average volume of a red blood cell. This is a calculated value derived from the hematocrit and the red cell count. 